\begin{tabular}{l}
\hline Jurnal Scripta Teologi dan Pelayanan Kontekstual \\
ISSN 2086-5368 (Print) \\
ISSN \\
Http://ejournal.stte.ac.id \\
Vol.2, No.1, pp. 48-64, 2017
\end{tabular}

\title{
Doing Theology Di Indonesia
}

\section{Obet Nego', Debby Christ Mondolu²}

'STT Ebenhaezer Tanjung Enim, Obetnego82@gmail.com

${ }^{2}$ STT Ebenhaezer Tanjung Enim, debtbychrist@gmail.com

\section{INFO ARTIKEL}

Sejarah Artikel:

Diterima : 03 April 2016

Direvisi : 10 April 2016

Disetujui: 15 April 2016

Dipublikasi: 24 April

2016

\section{Kata Kunci:}

keyword one, keyword two, keyword three.

Keywords:

keyword one, keyword two, keyword three.

\begin{abstract}
ABSTRAK
Berteologi atau Doing theology merupakan respon iman dari setiap orang yang menyadari keberadaan Allah dalam hidupnya. Dinamika dari teologi telah menghasilkan berbagai corak dalam berteologi. Di mana corak tersebut sangat dipengaruhi oleh pemikiran-pemikiran teologi yang berabad-abad telah muncul dan mempengaruhi banyak teolog di dunia ini untuk "berekspresi" dalam berteologi, termasuk di Indonesia. Dalam tulisan ini, akan menyajikan doing theology yang ada di bumi Indonesia, yang berangkat dari rentetan sejarah pemikiran dan fenomena-fenomena berteologi masa kini.

\section{ABSTRACT}

Doing theology is a faith response from everyone who realizes the existence of God in his life. The dynamics of theology have produced various patterns in theology. Where the pattern is greatly influenced by centuries of theological thought has emerged and influenced many theologians in the world to "express" in theology, including in Indonesia.

In this paper, we will present doing theology on Indonesian soil, which departs from a series of historical thoughts and theological phenomena today.
\end{abstract}

\section{PENDAHULUAN}

Sejak era modern hingga era post-modern, teologi terus mengalami keberagaman pola dan coraknya. Sesuai dengan hakikatnya yang dinamis, teologi terus berupaya menyesuaikan diri dengan tuntutan zamannya ke dalam pemikiranpemikiran teologi yang beragam. Tetapi, ironisnya, perjalanan dinamika teologi tersebut tidak disertai dengan pemahaman terhadap kebenaran Allah yang sejati, justru teologi semakin menjauh dari theos-nya yang merupakan sentral dari teologi itu sendiri.

Teologi, bila dimengerti sebagai respon manusia terhadap wahyu Allah, seharusnya dapat juga memberikan pengetahuan bagaimana manusia memiliki relasi dengan Allah, yang telah mewahyukan diri-Nya, dengan lebih baik. Seperti yang dirumuskan oleh para teolog abad pertengahan, bahwa: "Theology is taught by God, teaches of God and leads to God." Dalam hal ini, Allah adalah subyek teologi bukan obyek. Karena itu, dalam berteologi, apabila tidak menempatkan Allah sebagai subyek yang menyingkapkan kebenaran-Nya sendiri kepada umat-Nya, cenderung akan 
menilai Allah dengan ukuran manusia bahkan manusia itu sendiri yang dijadikan sumber teologi (antroposentris).

Pada masa kini, teologi-teologi yang antroposentris telah menjangkiti atmosfer doing theology atau berteologi di Indonesia. Mulai dari teologi yang didirikan di atas keyakinan pada keunggulan rasionalitas, fokus terhadap pengalaman pribadi yang emosional (emotional experience) hingga pengalaman transformasi spiritual-psikologi pribadi. Akibatnya, pola-pola berteologi tersebut telah mengesampingkan nilai-nilai spiritualitas yang sejati.

\section{METODE PENELITIAN}

Penelitian ini adalah penelitian kualitatif deskriptif yakni penelitian yang menggambarkan atau melukiskan objek peneliti-an berdasarkan fakta-fakta yang tampak atau sebagaimana adanya. Nawawi dan Martini (1996:73).

Teknik pengumpulan data dalam penelitian ini dilakukan dengan pengamatan atau partisipasi langsung dan penelaahan dokumen.

\section{HASIL DAN PEMBAHASAN}

Dari latar belakang pendahuluan dan metode yang dilakukan, penulis akan membahas tentang "Doing Theology di Indonesia". Dari pembahasan ini penulis memaparkan beberapa poin terkait doing theology di Indonesia yakni: Hakikat Doing Theology dan Bentuk-bentuk Doing Theology di Indonesia.

Untuk mengetahui deskripsi mengenai doing theology di Indonesia pada masa kini, tidaklah bisa dilepaskan dari runtut pemikiran teologi dalam sejarah kekristenan. Dalam hal ini adalah teologi dunia Barat. Karena faktanya, secara historis gereja-gereja di Asia adalah pewaris teologi Barat tersebut, termasuk Indonesia.

Sebelum era Renaissance, teologi memegang wibawa tertinggi sebagai Queen of the sciences. Namun, akibat perpaduan filsafat Plato dan Humanisme telah melahirkan kebangkitan dari kebebasan individu, yaitu Renaissance pada abad XIV, sehingga masa ini memaklumkan bahwa manusia sendiri adalah kaidah atau ukuran dari segala sesuatu, bukan lagi gereja ataupun teologi. Pengaruh Renaissance makin lama makin mempengaruhi berbagai aspek kehidupan, sehingga bertambah banyak orang secara khusus para cendikiawan mulai melepaskan diri dari kuasa Firman Tuhan. Begitu juga dengan ilmu pengetahuan dan kebudayaan mulai memisahkan diri dari ajaran-ajaran gereja.

Dalam perkembangannya lebih lanjut, Renaissance membuahkan filsafat Rasionalisme yang berkembang pada abad XVII. Rasionalisme sendiri berpijak pada diktum Rene Descrates sebagai Bapak Rasionalisme (1596-1650) yang mencanangkan cogito ergo sum. Pada masa yang sama, Renaissance juga membuahkan filsafat Empirisme yang bertentangan dengan filsafat Rasionalisme.

Era selanjutnya adalah zaman Pencerahan (Enlightenment) pada abad XVIII, di mana Immanuel Kant (1724-1804) mewakili puncak Rasionalisme dan Empirisme. Kant berupaya mengintegrasikan Rasionalisme dan Empirisme, seperti dalam tulisannya:

Isi pengetahuan adalah dari panca indera, tetapi bentuknya terjadi melalui kecerdasan. Akhirnya pengetahuan dibuat dengan kategori apriori dalam akal (misalnya: ruangan, waktu). Apa yang masuk akal telah dibentuk oleh kategori akal. Jadi akal tidak pernah mengetahui sesuatu di luar akal. Manusia hanya mengetahui sesuatu seperti di dalam 
diri-Nya sendiri (the thing to me), tetapi ia tidak dapat mengetahui sesuatu seperti ia di dalam diri-Nya sendiri (the this in itself). Maka semua yang ada hanya dapat diketahui secara subyektif bukan obyektif.

Dalam hal ini, Allah tidak dapat dialami dan diketahui secara obyektif dan riil, sehingga Kant menyangkali bukti-bukti dari eksistensi Allah dan mempertahankan bahwa manusia hanya dapat mengetahui Allah melalui penalaran. Pendekatan ini merupakan hasil dari Pencerahan, yang memandang tradisi dan otoritas Alkitab dengan kecurigaan dan mengklaim jasa dari penalaran.

Selanjutnya adalah Friedrich Schleiermacher (1768-1834). Di bawah pengaruh filsafat Romantisisme, Schleiermacher memberikan warna yang baru dalam teologi, yaitu mengutamakan feeling atau perasaan sebagai standart penilaian manusia. Bapak Teologi Modern ini, menginterpretasikan kembali seluruh teologi Kristen berdasarkan penekanan pada perasaan religius. Dengan feeling of absolut dependency, manusia dapat mengalami kehadiran Allah dalam pengalaman batiniahnya. Dengan kata lain, Allah tidak bisa dikenal dengan intelek manusia, atau mencari Allah di dalam alam atau di dalam Alkitab, melainkan di dalam perasaan khusus manusia itu sendiri.

Fase berikutnya adalah Neo-ortodoksi yang diusung pertama kali oleh Søren Kierkegard (1813-1855) dan selanjutnya dikembangkan oleh Karl Barth (1886-1968). Neo-ortodoksi merupakan reaksi terhadap kegagalan Liberalisme, di mana Karl Barth sendiri menentang subyektivitas Liberalisme, karena Liberalisme dianggap lebih mengutamakan kebebasan manusia dan pengalaman pribadi daripada kebenaran Allah. Namun pada kenyataannya, Barth juga jatuh ke dalam pemikiran yang sama dengan Schleiermacher, yaitu "batin-sentris." Barth juga mengajarkan bahwa Allah tidak dapat diketahui secara obyektif karena la adalah transenden. Dengan demikian, Allah harus diketahui secara subyektif melalui pengalaman pribadi.

Dari runtut pemikiran teologi dalam sejarah kekristenan tersebut, dapat terlihat adanya ketegangan antara "teologi intelektualis" dan "teologi pengalaman." Yang pertama, menekankan pada pemikiran filosofis kebenaran-kebenaran Kristen yang dideduksi dari kebenaran-kebenaran Alkitab. Yang kedua, lebih menekankan pada pengalaman transformatif melalui suatu perjumpaan (encounter) dengan yang llahi.

Dari pemaparan berbagai fenomena doing theology atau berteologi tersebut, mulai dari runtut sejarahnya hingga kenyataan berteologi pada masa kini, sepatutnyalah dibutuhkan teolog yang memiliki kecerdasan seimbang dalam berteologi. R.C Sproul menjelaskan hubungan kedua aspek ini (rasio dan emosi) lebih lanjut:

Alkitab ditujukan kepada intelek tanpa sekaligus memeluk semangat intelektualisme. Kehidupan Kristen tidak dimaksudkan untuk menjadi kehidupan yang semata-mata teoritis atau rasionalisme yang dingin. Kehidupan Kristen harus menjadi kehidupan yang bersemangat. Perasaan-perasaan sukacita, kasih dan pujian yang kuat berulang-ulang diperintahkan. Namun, perasaan-perasaan yang yang kuat itu merupakan respon terhadap apa yang kita pahami dengan pikiran kita sebagai sesuatu yang benar.

Ketika rasio dan emosi semakin seimbang, maka teolog tersebut semakin cerdas dalam berteologi. 


\section{A. Hakikat Doing Theology}

Sebelum memahami hakikat doing theology, perlu diketahui bahwa istilah "doing theology" sendiri adalah frase yang terjemahannya tidak ditemukan dalam kamus manapun. Namun dalam bahasa Inggris, istilah "doing theology" sudah baku, sehingga dapat diartikan "berteologi" atau "aktualisasi teologi" atau "berteologi dalam konteks."

Secara etimologi, kata "teologi atau theologia" berasal dari kombinasi dua kata Yunani, yaitu "theos" yang berarti "Allah" dan "logos" yang berarti "pengetahuan," "hikmat" atau "akal" atau "lego" (kata kerja) dapat diterjemahkan sebagai "ucapan," "susunan," "berbicara" (to lay, to arrange, to say). Jadi, secara harafiah "teologi" berarti berbicara tentang Allah atau apa yang dipikirkan atau dikatakan tentang Allah. Bila seseorang berkata: "Allah itu maha kuasa," "Allah itu ajaib" dan lain sebagainya, maka ia sedang berteologi. Dengan definisi seperti ini, maka semua orang bisa berteologi dan berhak untuk itu. Selain itu, teologi dapat juga dipahami sebagai pengajaran dan pengetahuan tentang Allah, sehingga teologi telah digolongkan sebagai suatu bidang studi dan ilmu.

Sedangkan pengertian doing theology atau berteologi adalah usaha manusia untuk menafsirkan, merumuskan, mengajarkan dan memberitakan penyataan Allah di dalam Alkitab, sehingga menjadi pengalaman konkrit. Demikian juga Hayes memberikan definisi dari Doing Theology:

Setiap orang yang sadar dan terarah merenungkan imannya dan membentuknya dengan teratur, sebenarnya sedang bertheologia. Orang-orang itu bukan hanya ahli teologi, tetapi juga kaum awam. Sehingga menurutnya, teologi adalah usaha untuk member bentuk pada semua segi dan dimensi iman yang dituangkan secara tertulis dalam rumusan kepercayaan. Ketika para teolog memikirkan kenyataan iman, segi-seginya yang beragam dan konteksnya yang melahirkannya, mereka melihat keperluan untuk mengorganisasikan dan menyusun pemikiran yang lebih teoritis dan sistematis ini dalam bentuk yang lebih bermakna untuk dimanfaatkan oleh paguyubanpaguyuban umat beriman. Dalam melaksanakan tugas ini, para teolog dengan sendirinya memandang Alkitab sebagai sumber yang tidak dapat dilepaskan, karena Alkitab masih berfungsi sebagai kaidah dalam membentuk iman dan praktik hidup dari paguyuban-paguyuban orang percaya zaman sekarang.

Jadi secara ringkas, Doing Theology adalah usaha orang Kristen secara sisitematik untuk memahami Allah, kehendak-Nya dan pekerjaan-Nya di dalam dan melalui Alkitab sebagai penyataan Allah yang tertulis. Lebih luas Jonathan Parapak memberikan penjelasan mengenai doing theology atau kegiatan berteologi:

Kegiatan berteologi adalah kegiatan yang berisi pergulatan ilmiah dan empiris. Berteologi berarti bergumul dengan pengetahuan tentang Tuhan. Studi teologi berarti suatu kegiatan akademik. Tentu saja teologi tidak semata-mata kegiatan akademik. Sebab, unsur theos atau Tuhan dalam kata "teologi" menunjukkan adanya pergulatan dengan Tuhan, suatu perjuangan untuk memaknai pengalaman kehidupan yang melampaui kegiatan ilmiah, suatu kegiatan yang melampaui pergumulan mengasah wacana atau diskursus. Berteologi berarti memaknai pengalaman kehidupan yang nyata dengan makna kemanusian yang lebih dalam dan lebih luas dari sekadar kegiatan berteori dan merumuskan kebenaran-kebenaran aksiomatis maupun dogmatis. Berteologi adalah kegiatan berwacana dan bernalar. Bernalar dalam arti merelevankan kebenaran wacana 
teoritis-dogmatis dalam kehidupan yang nyata. Bernalar berarti bergulat dengan keseharian hidup dalam kerangka memaknainya dalam konteks iman kepada ilahi.

Hal ini adanya keterkaitan yang erat antara orthodoxi, orthopathi dan orthopraxi dalam semakin memperjelas bahwa berteologi. Dengan kata lain, antara pengetahuan teoritis tentang Allah tidak terlepas dari kehidupan praktis pelaku teologi itu sendiri. Selain itu, aspek spiritualitas dalam teologi juga merupakan hal yang esensial, oleh karena kehidupan spiritualitas yang meniadakan kegiatan berteologi bukanlah kehidupan spiritual yang sehat. Demikian pula sebaliknya, berteologi yang merusak kehidupan rohani bukanlah kegiatan berteologi yang benar.

Hakikat doing theology atau berteologi memiliki jangkauan pemahaman yang tidak terbatas pada hal-hal yang teoritis mengenai Allah. Berteologi yang benar adalah upaya memahami dan mengetahui kebenaran tentang Allah dan pekerjaan-Nya melalui Alkitab tanpa menghilangkan nilai-nilai spiritualitas di dalamnya, oleh karena itu pengetahuan secara rasional tentang Allah harus dibarengi dengan pengalaman pribadi dengan Allah. Bahkan, selain berbicara mengenai relasi antara Allah dan umatNya, berteologi yang benar juga menyentuh pengalaman dalam kehidupan sosial sesama manusia, dengan tetap bersumber pada Alkitab sebagai sumber kajian teologi.

\section{B. Bentuk-Bentuk Doing Theology di Indonesia}

Adapun bentuk-bentuk doing theology tersebut adalah: doing theology kaum Rasionalis, doing theology kaum Pentakostalis dan ikaum Spiritualis.

\section{Doing Theology Kaum Rasionalis}

Kaum Rasionalis dalam berteologi menekankan pola pemikiran filosofis kebenaran-kebenaran Kristen yang dideduksi dari kebenaran-kebenaran Alkitab. Pemikiran mereka merupakan warisan dari pemikiran modern, yaitu berpijak pada diktum Rene Descrates. Teologi yang dihasilkan pun adalah teologi berdasarkan kebenaran yang diketahui oleh "aku" sebagai kebenaran internal.

Artinya, pembenaran terhadap suatu kepercayaan harus "diketahui" oleh subyek. Karena itu, dapat dipastikan teologi tersebut akan kehilangan obyektivitasnya.

\section{a. Doing Theology Berdasarkan Konsep Humanisme}

Humanisme merupakan filsafat yang melihat manusia, bukan Allah sebagai pusat sejarah dan pusat kehidupan. Dari Humanisme inilah mulai tumbuh suatu sikap bahwa manusia harus mencari jalan hidupnya sendiri. Banyak orang humanis akhirnya menyangkal adanya Allah (atheisme), ketidaktahuan apakah ada Allah atau tidak (agnostisisme) atau anggapan bahwa keberadaan Allah yang tidak berurusan lagi dengan alam ini (deisme). Eta Linnemann dalam bukunya "Teologi Kontemporer: Ilmu Atau Praduga?" menggambarkan kehidupan praksis para humanis:

Humanisme telah memutuskan untuk memandang manusia sebagai ukuran atau kaidah segala sesuatu. Itu berarti menarik mundur dari Allah, dan juga penolakan terhadap Allah yang Mahakuasa. Meskipun demikian pada permulaan humanisme sebagai dasar humanis masih beribadah dan saleh, walaupun bukan orang yang percaya sungguh-sungguh. Mereka berbicara mengenai Allah tidak didasarkan atas Firman Allah. Mereka memandang dirinya sebagai Kristen, tetapi 
mereka tidak tunduk kepada Firman Tuhan. Pikiran mereka didasarkan atas pemikiran manusia yang makin lama makin jauh dari Firman Allah.

Melalui konsep Humanisme inilah munculnya konsep berteologi yang berpusat pada manusia. Manusia menjadi kaidah suatu kebenaran, bukan Firman Allah. Sebagai akibatnya, tidak ada lagi yang mutlak di dunia ini, semuanya tergantung pada manusia itu sendiri yang pada dasarnya relatif sifatnya.

\section{b. Doing Theology Berdasarkan Konsep Liberalisme}

Konsep berteologi Liberalisme didirikan di atas keyakinan pada keunggulan rasionalitas, dan memiliki tujuan untuk menempatkan Allah dengan akal manusia, bahkan lebih jauh lagi menantang otoritas gereja dan tradisinya dengan rasionalisme. Liberalisme menempatkan penalaran manusia dan penemuan-penemuan ilmiah pada tempat utama, sehingga segala sesuatu yang tidak harmonis dengan penalaran dan ilmu pengetahuan harus ditolak.

Dalam konsep berteologinya, Liberalisme telah menolak doktrin historis dari iman Kristen dengan menekankan penemuan-penemuan dari sains dan berusaha untuk merekonsiliasi ilmu pengetahuan dan Alkitab. Konsekuensinya, pewahyuan, inkarnasi Kristus, penebusan ilahi, mukjizat dan hal-hal yang supranatural tidak dipercayai lagi bahkan ditolak dalam konsep berteologi mereka.

Jadi, dapat dipahami bahwa konsep Liberalisme lebih menitikberatkan kepada peranan otonomi manusia berupa pendewaan rasio manusia sebagai tolok ukur suatu kebenaran. Akibatnya, kebenaran absolout yaitu kebenaran Allah harus tunduk dalam konsep Liberalisme.

\section{c. Doing Theology Berdasarkan Konsep Historis Kritis}

Berteologi secara Historis Kritis adalah menegakkan otonomi manusia yang mutlak. Karena itu untuk memastikan suatu kebenaran secara obyektif, maka penilaian manusia dalam hal ini terhadap Alkitab, tidak boleh dipengaruhi oleh pihak luar manapun. Semua fakta-fakta dalam Alkitab secara kritis hanya akan diterima jika dapat dibuktikan dalam fakta historis yang riil.

Konsep Historis Kritis terhadap Alkitab juga bermula dari usaha dari para penafsir untuk mengerti kondisi sejarah penulisan kitab-kitab. Namun, pengaruh filsafat mengendalikan penelitian tersebut, sehingga mereka berusaha mengerti sejarah dari sudut sekuler yang mengabaikan unsur religius dan supranatural, yang disebut metode Historis Kritis. Metode ini dikenal dengan kritik tinggi (higher criticism), yaitu pola penelitian yang kritis, yang berangkat dari pendapat bahwa Alkitab adalah sebuah buku yang sama seperti semua buku yang lain.

Alhasil, seorang teolog Historis Kritis tidak dapat lagi meyakini bahwa seluruh Alkitab benar dan dapat dipercayai. Dengan demikian, ia juga tidak dapat lagi berbicara atas nama Allah dalam kehidupan pelayanannya.

\section{d. Doing Theology Berdasarkan Konsep Agnostisisme}

Agnostisisme dalam kenyataannya, merupakan salah satu konsekuensi dari argument Immanuel Kant mengenai pengetahuan manusia yang terbatas oleh kategori tempat dan waktu. Gagasan ini telah memengaruhi pemikiran dalam berteologi, yaitu 
Allah yang keberadaan-Nya melampaui waktu dan tempat, dan yang tidak bisa dikenal oleh manusia dapat dialami melalui konsep Allah yang dibentuk oleh akal murni.

R.E.D. Clark dalam "New Dictionary of the Christian Church" mencatat beberapa pandangan Agnostisisme:

Pandangan Agnostisisme ialah: (1) Kita harus menghentikan penghakiman mengenai semua isu mengenai yang tertinggi, seperti Allah, kehendak bebas dan kekekalan; (2) Menggambarkan suatu sikap sekuler mengenai kehidupan, bahwa Allah adalah tidak relevan dengan manusia modern; (3) Karena secara emosional seorang ditandai anti-Kristen dan sikap anti jabatan rohani; (4) Sebagai suatu sinonim untuk atheisme.

Dengan demikian, Allah tidak dapat dialami dan diketahui secara obyektif dan riil, oleh karena ketika memikirkan konsep tentang Allah, hasil pikiran itu tidak boleh diterima sebagai pengetahuan yang riil. Jika demikian, berarti manusia modern tidak memerlukan Allah dalam kehidupan mereka.

\section{e. Doing Theology Berdasarkan Konsep Relativisme}

Pada era Postmodern sekarang, kegiatan berteologi ditandai dengan semangat pencarian tanpa obyektivitas. Artinya, manusia masih mencari "sesuatu" untuk menjawab pertanyaannya dan mengisi kelaparan jiwanya, tetapi mereka yakin bahwa yang dicari itu bukan "kebenaran yang obyektif (objective truth)." Tidak heran, dengan demikian seluruh kebenaran Alkitab yang obyektif sifatnya, menjadi relatif sifatnya.

Konsep Relativisme dengan semangat subyektivitas, telah menjadikan Allah hanya sebuah simbol. Itulah yang terjadi, dan itu pula yang menjadi realita dalam kehidupan hamba-hamba Tuhan di era Postmodern ini. Tuhan hanyalah simbol, sehingga esensi dari kebenaran Firman-Nya atau core belief tidak lagi signifikan.

Pada akhirnya, setiap bagian dari core belief iman Kristen sudah kehilangan relevansinya. Tidak ada lagi kebenaran yang absolut, yang ada hanyalah kebenaran yang relatif sifatnya, berdasarkan kebenaran yang berasal dari "kebijaksanaannya" teolog itu sendiri.

\section{f. Doing Theology Berdasarkan Konsep Pluralisme}

Di tengah dunia yang pluralistik ini, konsep Pluralisme telah menyentuh wilayah agama bahkan teologi. Sifat dari eksklusivistik dari core belief iman Kristen menjadi inklusif demi toleransi dan adaptasi dalam kehidupan antar beragama. Dialog-dialog antar agama bukan hanya bersifat metodelogis, tetapi juga menyentuh wilayah "isi" dari pokok-pokok iman.

Kaum Pluralis ini menolak konsep kefinalitasan, eksklusivisme yang normatif, dan keunikan Yesus Kristus. Kristus bukan lagi satu-satunya penyelamat, melainkan salah satu penyelamat. Dengan demikian, kaum ini menggunakan konsep teosentris, dengan menempatkan Allah (theos) di pusat jagad agama.

Racun Pluralisme, pada akhirnya bermuara pada konsep dan praktik misi yang menghapuskan pemberitaan Injil kepada orang-orang belum percaya, diganti dengan upaya pencarian kebenaran Allah melalui persekutuan dengan orang-orang yang tidak seiman. Penjelasan doktrin Pluralisme mengenai adanya kebenaran dalam semua agama, telah mengorbankan kebenaran yang esensi dari core belief demi tegaknya toleransi dengan sesama. 


\section{Doing Theology Kaum Pentakostalis}

Di pihak lain, teologi kaum Pentakostalis tidak mengejar pengetahuan teologi melalui deduksi Alkitab, tetapi membangun teologi atas dasar pengalaman rohani (emotional experience). Kaum Pentakostalis, di tengah usahanya menghadapi tantangan kaum Rasionalis dalam mempelajari Alkitab, mencoba memindahkan iman dari wilayah pengetahuan ke wilayah pengalaman pribadi. Dengan kata lain, lebih menekankan pada pengalaman transformatif melalui suatu perjumpaan (encounter) dengan yang ilahi. Tetapi, Sama halnya dengan kaum Rasionalis, kaum Pentakostalis yang berteologi melalui dan berdasarkan pengalaman pribadi atau pengalaman dalam roh (experiencing the spirit) akan mengakibatkan teologi tersebut kehilangan obyektivitasnya.

\section{a. Doing Theology Melalui Karunia-Karunia Rohani \\ 1. Karunia rohani berupa nubuatan}

Karunia profetik ini adalah berbicara menyampaikan pemikiran dan keinginan hati Tuhan sebagaimana yang dinyatakan oleh Roh Kudus. Dengan pengertian lain, nubuatan adalah mendengarkan apa yang dikatakan oleh Tuhan dan kemudian menyampaikan pewahyuan tersebut kepada gereja di dalam waktu dan dengan caracara yang tepat dan sesuai. C. Peter Wagner mendefinisikan nubuat sebagai berikut: "Suatu kemampuan untuk menerima dan menyampaikan pesan Tuhan yang disampaikan secara langsung kepada umat-Nya melalui pengutaraan yang diurapi secara ilahi."

Langsung menerima nubuatan berarti menerima langsung dari sorga. Hal ini menjelaskan bahwa keluarbiasaan "berita langsung" ini bukan terletak pada isi berita, melainkan pada penerima berita tersebut. Laki-laki atau perempuan yang menerima berita tersebut dilihat sebagai pribadi yang luar biasa, sebab ia telah menerima berita langsung dari Tuhan sendiri. Pandangan-pandangan kaum ini tentang ucapan-ucapan nubuat, karunia-karunia nubuat dan wahyu justru merupakan penambahan kepada kitab suci. Akibatnya, menambahkan sesuatu kepada wahyu final Allah adalah menggerogoti keunikan dan wibawa Alkitab.

Dengan demikian, setiap usaha untuk menambahkan sesuatu kepada Alkitab dengan cara bernubuat, untuk mengklaim "wahyu tambahan" dari Tuhan, tanpa disadari telah menghasilkan pemujaan terhadap seseorang. Lebih dari itu, pesan dari orang-orang ini mempunyai otoritas apostolik, bahkan menyamakan mereka dengan otoritas Alkitab.

\section{Karunia rohani berupa bahasa Roh (Glossolalia)}

Sebenarnya istilah "bahasa roh" adalah istilah yang kurang tepat digunakan secara luas berdasarkan asal kata dalam Alkitab Yunani. Alkitab menggunakan kata "glossolalia," atau "bahasa lidah," berasal dari kata Yunani " $\gamma \lambda \omega ́ \sigma \sigma \alpha "$ (glossa) yang artinya "lidah," dan " $\lambda \alpha \lambda \omega \omega^{\prime}$ (lalô) yang berarti "berbicara." Jadi, istilah yang lebih tepat digunakan seharusnya adalah "bahasa lidah." Pemakaian istilah "bahasa roh" dikaitkan dengan pemahaman bahwa bahasa ini merupakan karunia yang diberikan oleh Roh Kudus sendiri, sehingga secara umum kini kedua istilah tersebut menjadi interchangable (bisa dipakai bergantian).

Hal ini sangat ditekankan dalam ajaran Pentakosta. Setiap orang Kristen harus berusaha untuk memperoleh pengalaman glossolalia ini, oleh sebabkeinginan besar 
untuk berglossolalia dan merasa diri superior sebagai orang Kristen (Great Expectancy dan Striving for Superiority). Tidak jarang, pengalaman glossolalia ini diklaim berisi berita dari Allah, seperti kebanyakan yang dipraktekkan oleh para pengkhotbah Kharismatik. Yakub B. Susabda menguraikan akibat dari berglossolalia yang salah, sebagai berikut:

Semuanya ini (Glossolalia) akan mengakibatkan: Alters consciousness (mengubah arah kesadaran), desensitizes consciousness (mengurangi sensitivitas kesadaran), dan membuka diri terhadap pengaruh dari luar, seperti: pengaruh sugesti dari orang-orang lain; roh jahat dan sebagainya. Tetapi tidak mungkin Roh Kudus, oleh karena Roh Kudus selalu bekerja sesuai dengan kebenaran Firman Allah. Roh Kudus tidak diperbudak oleh nafsu manusia. Roh Kudus tidak melayani orang yang tidak bertanggung jawab.

Meskipun demikian, glossolalia tetap menjadi fenomena di kalangan Kristen Kharismatik, yang mencari "kepuasan emosi" dalam beribadah. Tidaklah heran bahwa ekses-ekses negatif tidak dapat dihindari, oleh karena banyak di antara mereka yang dapat berglossolalia di luar anugerah Roh Kudus.

\section{Karunia rohani berupa rhema}

Derek Prince mendefinisikan "rhema"berdasarkan Roma 10:17 sebagai satu kata kerja dari bahasa Yunani yaitu " $\eta \mu \alpha \tau o \varsigma$ " dari kata dasar " $\rho \mu \alpha$ "yang berarti "berbicara," artinya perkataan yang diucapkan, yang terjadi dalam dimensi ruang dan waktu. Berdasarkan nats yang sama, Paul Yonggi Cho, seorang pengajar kharismatik sekaligus yang mempopulerkan istilah "rhema" ini, juga menyimpulkan bahwa "rhema" adalah ucapan yang khusus kepada seseorang dalam suatu keadaan tertentu.

Berbeda dengan "logos" yang bersifat umum, "rhema" lebih bersifat khusus dalam hati orang percaya. Hal ini ditegaskan oleh Djaka Christianto Silalahi:

Dalam kharismatik diakui bahwa rhema adalah inisiatif Allah, yaitu pekerjaan Roh Kudus dalam mengucapkan ulang Firman yang tertulis itu sehingga menjadi "hidup" bagi perorangan tertentu dan dalam situasi khusus pula. Baik logos (yang lebih bersifat umum, berlaku kepada semua orang) maupun rhema samasama berarti Firman Allah, akan tetapi perbedaan keduanya terletak pada dinamika pekerjaan Roh Kudus di dalam hati orang percaya secara individual, sedangkan logos adalah Firman Allah yang berlaku untuk orang Kristen pada umumnya.

Jika rhema yang didengar merupakan suara di dalam hati dan penerima suara tersebut menyakini bahwa itu adalah rhema dari Tuhan, maka apa yang didengar melalui "suara" pasti akan terjadi. Akibatnya fatal, orang-orang yang menerima rhema tersebut selalu menganggap Firman Allah tidak terlalu penting, karena yang lebih penting adalah wahyu yang langsung dari Allah.

Ketergantungan mutlak terhadap "rhema" dengan mengesampingkan otoritas dan kewibawaan Alkitab, tentu akan menciptakan ajaran-ajaran yang tidak sehat. Dengan menjadikan "rhema" sebagai "wahyu baru" melalui pewahyuan secara pribadi, akan menciptakan kegiatan berteologi yang subyektif.

\section{b. Doing Theology Pneumatocentris}

Dalam gerakan Pentakostalisme ini, Roh Kudus merupakan doktrin inti gerakan ini, di mana peristiwa historis dari pencurahan Roh Kudus memainkan peran sentral di 
dalam teologinya. Perhatian gerakan ini yang begitu besar kepada pencurahan Roh Kudus mengakibatkan seperti terjadinya persaingan antara Kristus dan Roh Kudus, antara iman dan pengalaman, antara Firman Allah dan Roh Kudus.

\section{Peranan Roh Kudus lebih dari Kristus}

Kaum Pentakostalis memiliki pemahaman mengenai peranan Yesus Kristus lebih rendah dari Roh Kudus. Menurut mereka, mengenal Yesus Kristus perlu untuk memperoleh pengampunan dosa saja, tetapi oleh Kristus mereka hanya mendapatkan "permulaan" kekayaan rohani saja (pengampunan, pendamaian, dan anugerah). Di pihak lain, ketika berbicara mengenai Roh Kudus terbukalah kepenuhan kekayaan, di mana Roh Kudus adalah manifestasi yang sempurna dari Yesus Kristus di dalam dunia saat ini. Karya Roh Kudus memberikan kemenangan atas kematian, kesempurnaan, kehidupan tanpa dosa, dan pemuliaan.

Dapat disimpulkan bahwa bagi kaum Pentakostalis ini, karya Roh Kudus melebihi karya Yesus Kristus. Karena, di dalam Roh Kudus dapat memperoleh "lebih banyak" daripada di dalam Kristus.

\section{Peranan Roh Kudus lebih dari Alkitab}

Firman Allah, sebagaimana yang telah diterima di dalam Alkitab, agaknya menjadi "sampah" bagi mereka yang membela spiritualitas Pentakostalisme ini. Menurut mereka, Firman yang tertulis (Alkitab) hanyalah penyataan atau wahyu yang "beku," tidak hidup lagi. Bagi mereka, yang penting untuk ditonjolkan sebagai hal yang lebih penting adalah kemungkinan mengalami pewahyuan yang dikerjakan Roh Kudus pada saat tertentu dan pada tempat tertentu, yaitu dalam hati orang percaya secara langsung dengan beragam bentuk.

Usaha mengesampingkan otoritas dan wibawa Alkitab dengan mengutamakan "wahyu baru," sama halnya dengan menolak keobyektivitasan Alkitab sebagai kebenaran mutlak. Hal inilah yang membuat kaum Pentakostalis selalu menentukan suatu kebenaran yang subyektif sifatnya, yang cenderung menjauh dari kebenaran Firman Allah.

\section{Peranan pengalaman Roh lebih dari iman}

Dalam pandangan kaum Pentakostalis, orang Kristen yang hanya hidup di dalam iman kepada Yesus Kristus baru sampai di lantai dasar keselamatan. Sedangkan orangorang yang telah mengalami baptisan di dalam Roh Kudus beserta manifestasimanifestasinya naik ke lantai kedua, tingkat yang lebih tinggi daripada hanya beriman saja.

Bagaimanapun kaum ini ingin meletakkan Alkitab sebagai wibawa tertinggi dalam hidup mereka, namun posisinya masih nomor dua di bawah pengalaman individual. Bahkan kaum ini mencoba mengambil Alkitab untuk dicocokkan dengan pengalaman yang mereka alami, bila tidak cocok, Alkitab akan diabaikan begitu saja. Tidak hanya itu saja, doktrin dan yang jelas dan yang telah tertata dengan rapi juga akan diabaikan.

Bagi kaum Pentakostalis ini, pengalaman rohani yang bisa menyentuh dan meningkatkan gejolak emosi mendapat tempat yang terutama dalam mencapai pertumbuhan iman. Karena itu, bagi mereka pengalaman rohani secara emosional adalah hal yang terpenting dalam beragama. 


\section{c. Doing Theology yang Eksklusif}

Rudy Budiman dalam tulisannya yang berjudul "Menentukan Sikap Terhadap Gerakan Kharismatik," telah mensinyalir adanya tindakan-tindakan eksklusif dari kaum Pentakostalis ini. Dalam kenyataannya, tidak jarang ada kelompok dari kaum ini yang lebih suka berkumpul dalam kelompoknya sendiri daripada mengunjungi kumpulankumpulan jemaat.

Kecenderungan eksklusivis "kharismatik" rupanya dipengaruhi oleh empat penekanan teologis yang membuatnya eksklusif, yaitu: KemakmuranPositif, Tanda dan Mukjizat, dan Neo Pentakostalisme Denominasional Historis. Wilfred J. Samuel dalam bukunya "Kristen Kharismatik" mengutip pengamatan Grant Swank mengenai kecenderungan eksklusivis Pentakostalisme:

Grant Swank membuat lima pengamatan sebagai berikut: (1) Pendapat yang umum bahwa kaum "Kharismatik" mempunyai perasaan kesombongan kerohanian. (2) Mereka dapat menjadi tidak peka terhadap disiplin Kristen. (3) Mereka dapat menjadi tidak dapat diajar. (4) Mereka mempunyai kecenderungan untuk memisahkan diri dari gereja kalau hal-hal yang terjadi tidak sesuai dengan cara mereka. (5) Mereka tidak mempunyai masalah dengan "perpindahan gereja" sebagaimana mereka pada umumnya kurang setia terhadap satu jemaat tertentu.

Hadirnya gerakan Pentakostalisme ini telah menuai beragam kontroversi. Mulanya untuk menjawab atas kelesuan dan kekakuan gereja-gereja tradisional dengan menghadirkan pola gereja yang lebih dinamis, kenyataannya hanya mendatangkan perpecahan dan perselisihan intern tubuh Kristus. Tidak lain karena, antusiasme yang diekspresikan bagi penerimaan karunia-karunia rohani itu tidak dibarengi dengan antusiasme untuk menghasilkan buah Roh.

\section{Doing Theology Kaum Spiritualis Gerakan Zaman Baru}

Gerakan Zaman Baru (GZB) atau New Age Movement (NAM) merupakan gerakan spiritual yang telah menyebar ke seluruh dunia dalam waktu tiga dasawarsa terakhir sejak dasawarsa 1960-an. Gerakan Zaman Baru (GZB) adalah kebangkitan kembali secara modern agama-agama dan tradisi kuno terutama yang berasal dari Timur (oriental), dan mempengaruhi kebudayaan umum dalam bentuk kebatinan timur, filsafat modern, psikologi, sains, termasuk fiksi sains (sains fiction), dan kontra kultur sekitar semesta, dan mengungkapkan kebebasan jiwa atau pikiran. GZB juga adalah suatu gerakan ekumenis timur dari kelompok okultisme, kelompok kesadaran baru yang membentuk jaringan bersama di dalam GZB.

Ron Rhodes memberikan pengertian istilah dari New Age Movement sebagai berikut:

The NAM is a loosely structured network of individuals and organizations who share a vision of a new age of enlightenment and harmony and who subscribe to a common "world view." The common world view is based on monism (all is one), pantheism (all is God), and mysticsm (the experience of oneness with the divine).

Ciri utama praktek GZB adalah berpusat pada pengalaman transformasi spiritualpsikologis pribadi, yang secara umum identik dengan ungkapan "pengalaman religius" yang patut dibagikan kepada orang lain. Kaum spiritualis GZB yang menjalankan 
kegiatan spiritualnya secara pribadi atau berkelompok, merupakan gerakan yang memayungi berbagai keyakinan, pemahaman dan ajaran yang berlaku bagi semua. Lagi pula GZB muncul sebagai reaksi atas sistem keagamaan, kepercayaan atau ajaran yang ortodoks, seragam dan baku.

Jadi, Gerakan Zaman Baru (GZB) adalah gerakan spiritualisme yang merupakan perpaduan dari banyak unsur kepercayaan dunia yang mencakup ajaran-ajaran agama, pandangan-pandangan umum dunia yang ada pada masa kini.

\section{a. Doing Theology Berdasarkan Monisme}

Istilah "monisme," secara etimologi berasal dari kata dasar "mono" yang berarti "satu," sehingga Monisme merupakan kepercayaan bahwa semua yang ada adalah satu. Dengan kata lain, Monisme adalah keyakinan bahwa segala sesuatu yang ada merupakan derivasi (penjabaran) dari sumber tunggal devine energy. Pada tingkat tertentu dapat digabungkan menjadi kesatuan dari semuanya. Akhirnya, tidak ada lagi perbedaan antara Allah, manusia, wortel atau sebuah batu karang. Ekstremnya lagi, bagi penganut paham Monisme tidak akan menyatakan bahwa "aku tidak menyerupai Allah," tetapi "aku adalah Allah."

Jika seseorang menganggap dirinya sendiri sebagai Tuhan dengan cara pengolahan kekuatan pribadi atau potensi diri manusia, maka dengan sendirinya ia menolak keberadaan Tuhan dalam hidupnya.

\section{b. Doing Theology Berdasarkan Pantheisme}

Secara etimologi istilah "pantheisme" berasal dari kata Yunani, "pan" berarti "semua" dan "theos" berarti Tuhan. Dalam arti metafisis, Pantheisme merupakan ajaran yang menganggap kenyataan mencakup semua suatu keberadaan tunggal, di mana hal-hal lainnya itu merupakan bagian penampakan atau proyeksinya. Sedangkan dalam arti agama, Pantheisme menganggap imanensi Tuhan ada di dalam mahlukmahluk. Gagasan lain mengenai Pantheisme adalah konsep God is all and all is god, Allah adalah segala sesuatu dan segala sesuatu adalah allah. Dengan kata lain, God within ourself yakni Allah di dalam diri sendiri.

Dengan demikian, jika menganggap segala sesuatunya (kekuatan alam) adalah Allah, maka penganut paham Pantheisme ini tidak akan mengakui adanya Allah yang berpribadi.

\section{c. Doing Theology Berdasarkan Spiritisme}

Di kalangan kaum GZB, Spiritisme merupakan salah satu ajaran inti gerakan ini. Spiritisme merupakan kepercayaan yang beranggapan bahwa manusia sanggup berhubungan dengan roh-roh orang yang telah meninggal. Melalui praktek ini, kaum GZB menyakini bahwa roh-roh tersebut mampu memberikan wawasan kepada seseorang mengenai etika dan makna kehidupan di bumi. Mengenai praktek mistik ini, Herlianto menambahkan:

Roh orang mati itu dapat dipercaya berada di dekat manusia, lebih-lebih bila seseorang baru meninggal, dan roh orang itu dapat berhubungan dengan orangorang yang masih hidup. Mereka dipercayai dapat memberi nasihat, menolong, menghibur, dan memberi petunjuk-petunjuk bagi yang hidup, tetapi mereka juga dapat membalas dendam, menghantui, mengancam dan mengganggu. Berdasarkan hal itu dapat dimengerti mengapa orang-orang percaya berusaha untuk dapat melakukan kontak dan berhubungan dengan roh-roh itu. 
Hal ini membuktikan bahwa antara paham spiritisme dan animisme memiliki keterkaitan yang erat. Ketergantungan terhadap roh-roh orang meninggal, menjadikan ritual mereka sarat dengan nuansa mistik yang kental.

\section{d. Doing Theology Berdasarkan Psikologi Transpersonal}

Dalam pergerakannya, GZB juga memasuki ranah psikologi manusia dengan cara mengeksploitasi kemampuan diri (self actualizing). Kepercayaan mengenai Allah (teologi) makin digantikan tempatnya dengan psikologi sebagai pusat pengertian mengenai diri manusia. Kekuatan psikologi ini dinamakan Psikologi Transpersonal, di mana memiliki beberapa kapasitas di dalamnya, yaitu: kesatuan kesadaran, pengalaman puncak, pengalaman mistik, aktualisasi diri, kesatuan (oneness), kesadaran kosmis, dan fenomena transendental. Manusia mencari jawab atas kebutuhan dirinya, bukan dengan melihat kembali kepada Allah dan kebenarannya tetapi kepada imu jiwa (psikologi) yang sekarang menjadi agama baru bagi manusia.

Psikologi Transpersonal membuka diri kepada berbagai-bagai tradisi paham kebatinan Timur yang bersifat pantheistik dan monoistik (hanya ada satu keberadaan tunggal), dan sering sekali memasukan dalam praktek latihannya, seperti meditasi dan yoga. Hal ini menarik sekali, oleh karena mencoba menggabungkan gengsi rasionalisme Barat dengan mistisisme Timur yang eksotis. Sekalipun Psikologi Transpersonal mengikatkan diri dengan kebijaksanaan Barat, ia juga merangkul okult. Pemahaman Psikologi Transpersonal ini jelas sekali mengesampingkan keberadaan Tuhan dan menggesernya dengan kemampuan diri manusia. Penggabungan berbagai prinsip dari aliran-aliran, dijadikan sarana dalam mengekspoitasi potensi diri manusia, yang secara sadar telah menjadikan manusia sebagai pusat segala sesuatu (antroposentris).

\section{KESIMPULAN}

Deskripsi doing theology atau kegiatan berteologi sebagaimana yang diuraikan di atas, telah memberikan gambaran bahwa pola dan corak berteologi di Indonesia dewasa ini sangat beragam sifatnya. Secara historis, gereja di Indonesia sebagai pewaris teologi-teologi Barat, sedikit banyak telah dipengaruhi oleh pemahaman berteologi yang menjunjung tinggi otonomi akal. Akibatnya, Alkitab yang adalah Firman Allah harus dikaji ulang untuk menentukan keabsahannya. Kebenaran yang obyektif menjadi relatif dan subyektif, bahkan hal-hal yang esensi dari iman Kristen harus dikorbankan demi berdirinya toleransi di tengah dunia pluralistik sekarang.

Selain itu, pola dan corak berteologi di Indonesia juga diwarnai dengan hadirnya teologi Pentakostalisme atau aliran yang mengutamakan pengalaman dengan Roh Kudus. Pribadi ketiga dari Trinitas, yaitu Roh Kudus merupakan doktrin sentral dari aliran ini, sehingga pengalaman iman di dalam Kristus tidaklah sempurna jika tidak mengalami pengalaman kedua di dalam Roh Kudus.

Kaum Pentakostalis mengklaim diri mereka sebagai jawaban atas kekakuan dan kebekuan gereja tradisional (Calvinis dan Lutheran) selama ini. Dengan memberikan penekanan yang lebih besar kepada pengalaman iman secara emosional (emotional experience), diyakini akan melahirkan pengalaman iman yang lebih dinamis, berupa mengoptimalkan karunia-karunia rohani. Namun, antusiasme terhadap karunia-karunia Rohani tersebut tidak disertai dengan antusiasme terhadap buah Roh. Justru 
pengalaman-pengalaman rohani yang bersifat pribadi, bertendensi melahirkan eksklusivisme dan kesombongan rohani.

Gerakan Zaman Baru (GZB) atau New Age Movement (NAM) juga memberikan warna baru dalam berteologi di era Postmodern ini. Gerakan ini merupakan gerakan spiritualisme yang terdiri dari perpaduan agama-agama dunia. Selain menggabungkan prinsip-prinsip dari berbagai aliran, gerakan ini juga hadir dalam rupa pengembangan transformasi spiritual-psikologi pribadi. Dengan mengeksploitasi kemampuan diri, manusia tidak lagi melihat lagi keberadaan Allah, tetapi lebih ke arah mengoptimalkan kekuatan jiwa atau psikologi pribadi sebagai kekuatan. Selain itu, kepercayaan mengenai Allah (teologi) makin digantikan tempatnya dengan psikologi sebagai pusat pengertian mengenai diri manusia. 


\section{KEPUSTAKAAN}

Aritonang, Jan S. 2008 Berbagai Aliran di Dalam dan di Sekitar Gereja, Jakarta: BPK

Arthur Jr., John F. Gunung Mulia, $1988 \quad$ Apakah Karismatik Itu?, Lawang: Eklesia

Berkhof, H. I.H. Enklaar

1999 Sejarah Gereja, Jakarta: BPK Gunung Mulia

Boeker, T.G.R. 1998 "Teologi Modern dan Teologi Injili," dalam Dipanggil untuk Melayani, Batu: Literatur YPPII

Budiman, Rudy 1982 "Menentukan Sikap Terhadap Gerakan Kharismatik" dalam

Cho, Paul Yonggi 1987

Enns, Paul Gerakan Kharismatik Apakah itu?, Jakarta: BPK Gunung Mulia 2007 Erickson, Millard J. 2004

Dimensi keempat, Jakarta: Immanuel

The Moody Handbook of Theology, Malang: Literatur SAAT

Teologi Kristen vol I, Malang: Gandum Mas

Fernando, Ajith $2006 \quad$ Supremasi Kristus, Jakarta: Momentum

Groothuis, Douglas R. 1996 Membuka Topeng Gerakan Zaman Baru, Jakarta: Stephen Tong Evangelistic Ministries International

Gunawan, Hendra 2006

“Gereja, Teologi, dan Pertumbuhan Rohani," Jurnal Amanat Agung vol 2 no 1,April

Hananiel, Nugroho S. 1987 Mari Berteologi, Malang: Gandum Mas

Hayes, John 1993 Pedoman Penafsiran Alkitab, Jakarta: BPK Gunung Mulia

Heidler, Robert 1999 Mengalami Roh, Jakarta: Nafiri Gabriel

Herlianto $1990 \quad$ Humanisme dan Gerakan Zaman Baru, Bandung: Kalam Hidup

Kurnia, Lydia 2005

Linnemann, Eta 1991

" Keluarga Kristen dalam Era Postmodernisme," Jurnal Transformasi vol I no 1, Agustus

Lumintang, Stevri Indra

2004 2006

Teologi Kontemporer Ilmu Atau Praduga?, Batu: Institut Injil Indonesia

Theologia Abu-Abu: Pluralisme Agama, Malang: Gandum Mas Theologia dan Misiologia Reformed, Batu: Literatur PPII 
Manton, M.E. 2003

Maris, Hans

2004 Gerakan Karismatik dan Gereja Kita, Jakarta: Momentum

Mudhofir, Ali

1989 Kamus Teori dan Aliran dalam Filsafat, Yogyakarta: Liberty

Nash, Ronald $\mathrm{H}$.

2008

Firman Allah dan Akal Budi Manusia, Jakarta: Momentum,

Parapak, Jonathan

2002

Prince, Derek

1993

Pembelajar dan Pelayan, Jakarta: Institut Darma Mahardika,

Rhodes, Ron

$1995 \quad$ New Age Movement, Michigan: Zondervan Publishing House

Ryrie, Charles Caldwell

1983 Teologi Kekinian, Surabaya: YAKIN

Samuel, Wilfred J.

2007

Kristen Kharismatik: Refleksi Atas Berbagai Kecenderungan Pasca

Kharismatik, Jakarta: BPK Gunung Mulia

Sihombing, Lotnatigor

1990

"Doktrin Kontemporer" dalam Doktrin dan Konteks, Batu: Institut Injil Indonesia

2004 Sistematika 1, Jakarta: Sekolah Tinggi Teologi Yordan Alyamin

Silalahi, Djaka Christianto

2004 Karismatik Bercampur dengan Perdukunan?,Yogyakarta: Yayasan

ANDI

Singgih, Gerrit

2005 Mengantisipasi Masa Depan: Berteologi dalam Konteks di Awal

Milenium III, Jakarta: BPK Gunung Mulia,

Sudarmanto, Gunaryo

2009 Menjadi Pelayan Kristus yang Baik, (Batu: Departemen Multimedia YPPII

Susabda, Yakub B.

2007

"Hamba Tuhan di Era Post-Mo" dalam God's Fiery Challenger for Our Time, Benyamin F. Intan (Ed.), Jakarta: Reformed Center for Religion and Society, STEMI

1986 Pastoral Konseling, Malang: Gandum Mas

1990 Teologi Modern I, Jakarta: Lembaga Reformed Injili Indonesia

Tomatala, Yakob

2004

Tong, Joseph

2007

Yesus Kristus Juruselamat Dunia: Satu-Satunya Jawaban Atas Masalah Manusia, Jakarta: YT Leadership Foundation

"Penilaian Kritis Terhadap Beberapa Pemikiran Teologi Kontemporer di Dalam Kekristenan", Jurnal Stulos vol 6 no 2, September

1998 Foundation of Philosophical Theology, Pacet: ICTS 
Wright, Christ

2003

Tuhan Yesus Memang Khas Unik, Jakarta: Yayasan Komunikasi Bina Kasih/ OMF 